
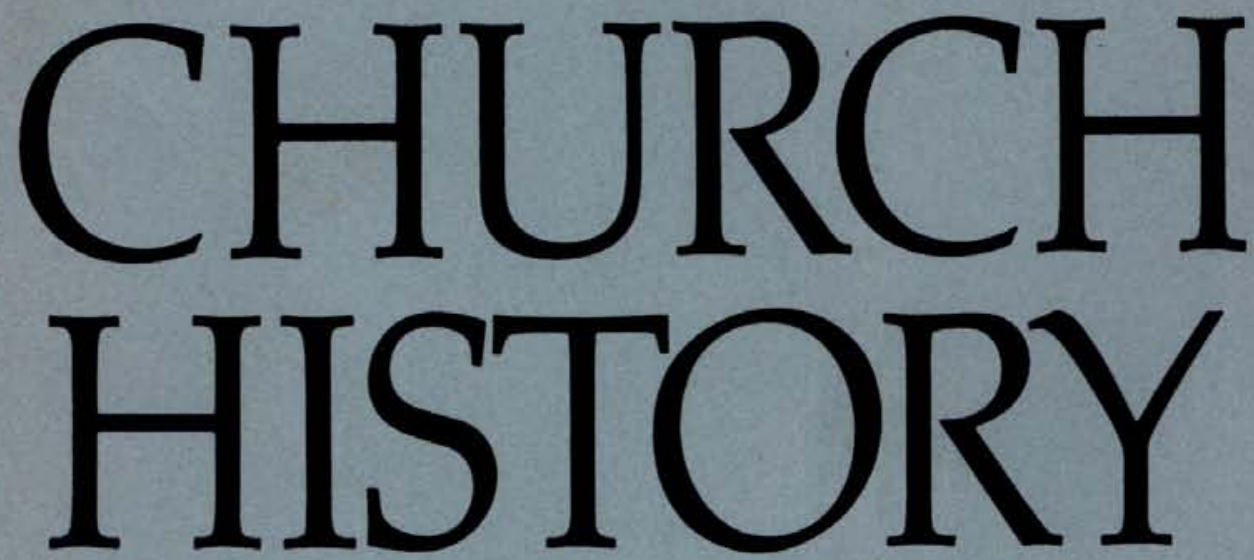

AMERICAN SOCIETY OF CHURCH HISTORY, DECEMBER, 1980 


\title{
PRESIDENT
}

ROBERT M. KINGDON, University of Wisconsin

\author{
PRESIDENT-ELECT \\ WiLLIAM R. HUTCHISON, Harvard University \\ SECRETARY, TREASURER \\ William B. MiLler, Wallingford, PA \\ ASSISTANT SECRETARY \\ Stuart C. Henry, The Divinity School, Duke University
}

EDITORS

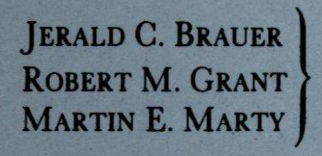

The Divinity School, University of Chicago

\section{MEMBERS OF THE COUNCIL}

Class of 1980

Caroline W. Bynum

E. BROOKS HOLIFIELD

DAVID O'BRIEN

ALBERT J. RABOTEAU

Paul S. SEAver

Class of 1981

WILLIAM J. BOUWSMA

MARILYN J. HARRAN

SCOTT H. HENDRIX

ROBERT A. KOLB

J. SEARS MCGeE

Class of 1982

JANE DOUGLASS

KARLFRIED FROEHLICH

FRED J. HOOD

WINTON U. SOLBERG

ROBERT F. TRISCO

The Society was founded in 1888 by Philip Schaff, was reorganized in 1906 and was incorporated by act of the Legislature of the State of New York in 1916. 
Vol. 49 December, $1980 \quad$ No. 4

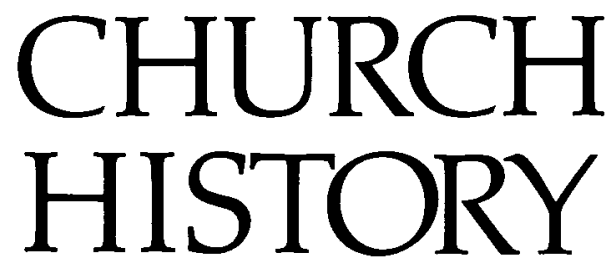

Published quarterly by

THE AMERICAN SOCIETY OF CHURCH HISTORY

(C) 1980, The American Society of Church History 


\title{
CHURCH HISTORY EDITORS
}

Jerald C. Brauer

ROBERT M. GRANT

MARTIN E. MARTY
The Divinity School, University of Chicago

\section{with the cooperation of}

\author{
Robert T. HaNdY, Union Theological Seminary \\ James Hennesey, Boston College \\ WinTHROP S. HUDSON, Colgate-Rochester Divinity School \\ James Hastings Nichols, Princeton Theological Seminary \\ Jaroslav Pelikan, Yale University \\ GeORge H. Williams, Divinity School, Harvard University
}

assistants to the editors

KaTHARINE L. DVORAK

MARVIN L. BERGMAN

Church History is published quarterly in March, June, September and December by the American Society of Church History. Subscription prices are $\$ 20.00$ a year (students with recommendation of professor and persons having been society members for five years and now retired from professional life - $\$ 10.00$ ); $\$ 5.50$ for single issues; $\$ 1.00$ extra should be added for foreign countries. Please make all remittances payable to the American Society of Church History. Subscription applications, renewals, changes of address, claims for missing numbers, and orders for single copies of current or back issues should be sent to William B. Miller, $305 \mathrm{E}$. Country Club Lane, Wallingford, PA 19086. Claims for missing numbers will be honored without charge if made within two months following the regular month of publication.

Microfilm reproductions of The American Society of Church History Papers, series I and II, and of Church History, vols. 1-17 (1932-48), are available from the ATLA Board of Microtext. Orders for these reproductions as well as inquiries about microfilm portions and xerox copies should be sent to Charles Willard, Princeton Theological Seminary, Speer Library, P.O. Box 111, Princeton, New Jersey 08540.

Microfilm reproductions of Church History starting with vol. 18 (1949) are available to subscribers and members of the society from University Microfilms, $300 \mathrm{~N}$. Zeeb Road, Ann Arbor, Michigan 48106.

An Index for both series of Papers and for Church History, vols. 1-30 (1961), is available at $\$ 2.00$, and an Index for Church History, vols. 31-39 (1970), is available at $\$ 2.50$ from the Treasurer, William B. Miller, at the address given above. Book reviews are indexed or abstracted in Book Review Index, Historical Abstracts and America: History and Life.

Manuscripts and books fo. review should be sent to Church History, Swift Hall, 1025 E. 58th St., Chicago, Illinois 60637.

Manuscripts submitted for consideration must be typed double-spaced on sturdy paper; footnotes must be typed double-spaced on separate pages following the text. Manuscripts exceeding twenty-five pages in length (including footnotes) cannot be considered. Please submit two copies of the manuscript (no carbons) and include correct return postage.

Advertising orders and requests for permission to quote should be addressed to the editorial office in Chicago.

Church History is printed by Science Press, Ephrata, Pennsylvania. Second-class postage paid at Wallingford, Pennsylvania and additional mailing offices. 


\section{CONTENTS}

375 The Church and Béla III of Hungary (1172-1196): The Role of Archbishop Lukács of Esztergom

ZOLTAN J. KosZTOLNYIK

387 Ecumenicity or Orthodoxy: The Dilemma of the Protestants in the Lands of the Austrian Habsburgs

David P. Daniel

401 The Second Great Awakening in Connecticut: Critique of the Traditional Interpretation

RICHARD D. SHIELS

416 "A Man of the Hour and the Time": The Legacy of Gustav Niebuhr

William G. Chrystal

433 The Portrayal of Christianity in the History Textbooks of Nazi Germany

Gilmer W. BLACKBURN

\section{Book Reviews}

Ruether, Rosemary and McLaughlin, Eleanor, eds., Women of Spirit: Female Leadership in the Jewish and Christian Traditions..................................... Sandra S. Sizer

Schoedel, William R. and Wilken, Robert L. eds., Early Christian Literature and the Classical Intellectual Tradition: In Honorem Robert M. Grant ............... Rowan A. Greer Gibson, Elsa, The "Christians for Christians" Inscriptions of Phrygia............................... Frederick W. Norris

Benoit, André; Philonenko, Marc; and Vogel, Cyrille, eds., Paganisme, Judaïsme, Christianisme: Influences et affrontements dans le monde antique: Mélanges offert à Marcel Simon.

Robert Wilken

Rambaux, Claude, Terlullien face aux morales des trois premiers siècles ............................. Robert M. Grant

Speck Paul, Kaiser Konstantin VI: Die Legitimation einer fremden und der Versuch einer eigenen Herrschaft: Quellenkritische Darstellung von 25 Jahren byzantinischer Geschichte nach dem ersten Ikonoklasmus ... . George T. Dennis, S.J.

Minninger, Monika, Von Clermont zum Wormser Konkordat: Die Auseinandersetzung um den Lehnsnexus zwischen König und Episkopat ......................... Thomas E. Morrissey Barlow, Frank, The English Church, 1066-1154............ Richard W. Pfaff Millor, W. J., S. J. and Brooke, C. N. L., eds., The Letters of John of Salisbury. Volume 2, The Later Letters (11631180) Frances A. Underhill 
Idung of Prüfening, Cistercians and Cluniacs: The Case for Cîteaux. A Dialogue between Two Monks. An

Argument on Four Questions ..............

Bede K. Lackner

Bouchard, Constance Brittain, Spirituality and Administration: The Role of the Bishop in Twelfth-

Century Auxerre . . . . . . . . . . . . . . . . . Philip F. Gallagher

Colledge, Edmund, O.S.A. and Walsh, James, S.J., eds., $A$

Book of Showings to the Anchoress Julian of Norwich . . . Caroline Walker Bynum

Finlay, Ian, Columba . . . . . . . . . . . . . . . . . Joseph F. Kely

Nicol, Donald M., Church and Society in the Last Centuries of Byzantium ........................Walter Emil Kaegi, Jr.

Kieckhefer, Richard, Repression of Heresy in Medieval Germany .................. Jeffrey B. Russell and RaGena DeAragon

Bendix, Reinhard, Kings or People: Power and the Mandate to Rule ........................... Gerald Christianson

Dickinson, J. C., The Later Middle Ages: From the Norman Conquest to the Eve of the Reformation . . . . . . . . . Charles F. Lasher

Olivier, Daniel, The Trial of Luther ............... Hans-Fredrik Gustafson

Rothrock, George A., The Huguenots: A Biography of a

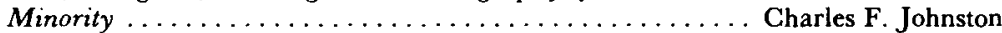

Maruyama, Tadataka, The Ecclesiology of Theodore Beza: The Reform of the True Church ......................Jill Raitt

Kreider, Alan, English Chantries: The Road to Dissolution . . . . . . . Horton Davies

Firth, Katharine R., The Apocalyptic Tradition in

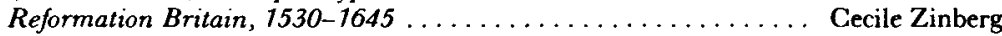

Freiday, Dean, The Bible: Its Criticism, Interpretation and Use in Sixteenth and Seventeenth Century England ...

Keeler, Mary Frear; Cole, Maija Jansson; Bidwell, William B.; and Johnson, Robert C., eds., Commons Debates $1628 \ldots \ldots \ldots \ldots \ldots \ldots \ldots \ldots$. . . . . . . . . . . . . . . . . . . . . . . . . . . . . . . . . .

Capp, Bernard, English Almanacs, 1500-1800: Astrology and the Popular Press . . . . . . . . . . . . . . Brian P. Copenhaver

Sanders, Ronald, Lost Tribes and Promised Lands: The Origins of American Racism

Thomas V. Peterson

Perry, Lewis and Fellman, Michael, eds., Antislavery Reconsidered: New Perspective on the Abolitionists. . . . . . . David W. Wills

O'Donnell, J. Dean, Jr., Lavigerie in Tunisia: The Interplay of Imperialist and Missionary.

Patrick W. Carey

Larkin, Emmet, The Roman Catholic Church and the Plan of Campaign in Ireland, 1886-1888

Larkin, Emmet, Roman Catholic Church in Ireland and the Fall of Parnell, 1888-1891.

Yearley, Lee H., The Ideas of Newman: Christianity and Human Religiosity ........................ Paul Misner

Wilkinson, Alan, The Church of England and the First World War

Živojinović, Dragan R., The United States and The Vatican Policies, 1914-1918.

William H. Petersen

Leone, Mark, Roots of Modern Mormonism Robert Trisco

Flower, Elizabeth and Murphey, Murray G., A History of Philosophy in America .................... Edwin S. Gaustad

Kremer, Ulrich Michael, Die Reformation als Problem der amerikanischen Historiographie.

Woodbridge, John D.; Noll, Mark A.; and Hatch, Nathan O., The Gospel in America: Themes in the Story of American Evangelicals ....................... C. C. Goen 
Piepkorn, Arthur C., Profiles in Belief: The Religious

Bodies of the United States and Canada. Volume 3,

Holiness and Pentecostal; Volume 4, Evangelical,

Fundamentalist and Other Christian Bodies ............. Robert T. Handy

Smart, Ninian, In Search of Christianity: Discovering the

Diverse Vitality of the Christian Life ................ Emil Oberholzer

Hastings, Adrian, A History of African Christianity, 1950-

1975 .

Paul R. Dekar

\section{Booknotes}

Desroche, Henri, The Sociology of Hope ................... Jon Butler

Fontaine, J. and Perrin, M., eds., Lactance et son temps:

Recherches actuelles: Actes du IV' colloque d'études

historiques et patristiques, Chantilly, 21-23 septembre

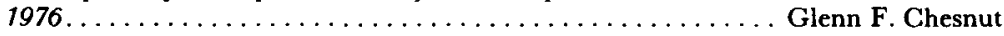

Miquel, Pierre, La Vie monastique selon Saint Benoît . . . . . . . Robert S. Urekew

Clemoes, Peter, ed., Anglo-Saxon England $8, \ldots \ldots \ldots \ldots \ldots$ William A. Chaney

Laiou-Thomadakis, Angeliki E., Peasant Society in the Late

Byzantine Empire: A Social and Demographic Study.......... Cyril Mango

Hudson, Anne, ed., Selections from English Wycliffite Writings ................................ Charles W. Brockwell, Jr.

Victor, Joseph M., Charles de Bovelles, 1479-1553: An Intellectual Biography...................... Robert D. Linder

Lønning, Inge and Rasmussen, Tarald, Martin Luther

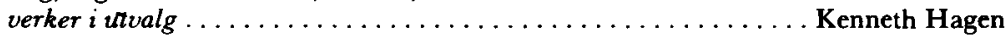

Aland, Kurt, Four Reformers: Luther, Melanchthon, Calvin, $Z$ wingli ............................... Dueck

Goertz, Hans-Jürgen, Radikale Reformatoren: 21 biographische Skizzen von Thomas Müntzer bis

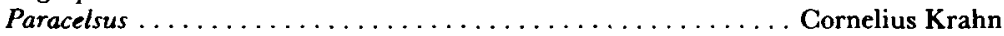

Nieto, Jose C., Mystic, Rebel, Saint: A Study of St. John of the Cross ................................. E. Ann Matter

Temperley, Nicholas, The Music of the English Parish Church................................. Horton Davies

Aarflot, Andreas, Hans Nielsen Hauge: His Life and Message............................ Trygve R. Skarsten

Brandenburg, Hans, The Meek and the Mighty........... Charles A. Frazee

Parker, Harold M., Studies in Southern Presbyterian

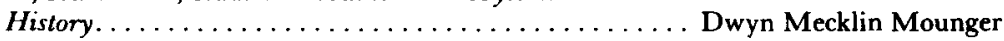

Bjork, Daniel W., The Victorian Flight: Russell Conwell and the Crisis of American Individualism. ............. Philip D. Jordan

Ljungmark, Lars, Swedish Exodus . . . . . . . . . . . . . Trygve R. Skarsten

Rupp, George, Culture-Protestantism: German Liberal Theology at the Turn of the Twentieth Century. .

Isetti, Ronald Eugene, F.S.C., Called to the Pacific: $\boldsymbol{A}$ History of the Christian Brothers of the San Francisco District, 1868-1944.

Dooyeweerd, Herman, Roots of Western Culture: Pagan, Secular and Christian Options John C. Fout 